\title{
High-rise housing in the city of Samara: the first steps on the path to sustainable development
}

\author{
Tatiana Ya. Vavilova ${ }^{*}$, Elena Yu. Makeeva ${ }^{2}$ \\ ${ }^{1}$ Samara State Technical University, 443100, Molodogvardeyskaya St., 244, Samara, Russia \\ ${ }^{2}$ Samara State University of Education and Social Sciences, 65 / 67, M. Gorky St., 443099, Samara, \\ Russia
}

\begin{abstract}
This paper outlines theoretical background of high-rise housing and discusses its design experience. It particularly focuses on environmental, social and economic aspects which are among crucial sustainable development issues. The authors dwell upon the implementation of innovative solutions that meet principles and goals of sustainable development and take construction objects built in Samara (which is one of the largest metropolises in Russia) as an example. The research also investigates the quality of project designs and reveals techniques corresponding to the "green standards". It considers the issues of practicing high-rise building construction in specific urban conditions and identifies unresolved architectural problems.
\end{abstract}

\section{Introduction}

The largest cities of Russia hold considerable potential for urban construction growth. These cities historical development came together with changes in their ecological state, with transformation of social processes and with adjustment of principles of territorial development control to new economic conditions. The period of industrialization turned out to be the most difficult. This period was associated not only with the emergence of various manufactures and plants, but also with the introduction of typical projects into house construction practice. By 1980s new residential areas (the so-called micro-districts) were built in most Russian cities. These micro-districts designers did not aim at increasing living standards but just at meeting the standards of living space. It should be noted that, to a certain extent, such an approach corresponded with capabilities of the Soviet economy, in which the concepts of "quality of life" or "living standards" did not exist.

The stage market relations formation in Russia coincided with the development of the concept of sustainable development in western countries. The concept of sustainable development inextricably links the issue of improving the quality of life with the improvement of ecological condition, social services infrastructure, and with small business growth. The revival in the Russian Federation such concepts as "ground rent" and "property value" led to the creation of new mechanisms for controlling the growth of cities and to the introduction of urban land use effective management techniques. At present, raising the

\footnotetext{
* Corresponding author: vatatyan63@yandex.ru
} 
number of storeys and socio-infrastructural saturation of newly constructed residential buildings and complexes are considered to be promising trends in urban development [1,2].

\section{Methods}

High-rise residential buildings design used to be an important issue in Russia even in Soviet times. The so-called "Stalin's skyscrapers", built in Moscow in the late 40s - early 50s of the XX century, are known as the most ambitious project of that time. Two of these skyscrapers (on the Kudrinskaya Square and on the Kotelnicheskaya Embankment) are residential buildings. The building on the square near Red Gate is an administrative-and-residential one, and the other two buildings are the hotels "Ukraine" and "Leningradskaya". There are also apartments located in the lateral wings of the main building of Moscow State University and the hotel "Ukraine".

In the late 50s political and economic priorities in the USSR changed. It led to the development of low-rise mass house construction. Only in the late1970s - early 1980s building technologies were and designers returned to the idea of erecting residential high-rise buildings. A new scientific basis of high-rise buildings architectural design appeared in the end of this period.

\subsection{Retrospective review of the scientific basis for the design and construction of high-rise residential buildings in Russia}

In the Soviet times, one of the first dissertations in architecture considering the evolution of the number of storeys in residential buildings was the work of D. Fisenko (1990). In 1992 I. Melnikova introduced principles of forming compositions of multi-storey residential houses facades, and in $1994 \mathrm{~L}$. Petrova offered a range of techniques to improve living environment in such houses. B. Gandelsman (1997) studied the problem of center-pieces (dominants) in the historical part of Moscow. N. Demidov in 2005 raised issues of the formation of multistorey centers in historical parts of Ekaterinburg. S. Lyzhin's dissertation (2006) became one of the most comprehensive analytical studies on the architecture and structure of the Urals cities housing stock. D. Sin considered the aspects of evolution of Novosobirsk multi-storey buildings functional features starting his research in the beginning of the XX century up to the early XXI century (2007). In 2009 P. Zueva made an attempt to analyse genesis and evolution of high-rise buildings construction in the United States. I. Zhdanova examined industrial residential high-rise buildings in her dissertation in 2013. She introduced architectural methods of evaluation and improving consumer properties of living environment (2013). Yu. Skoblitskaya (2013) analyzed architectural and space-planning design of service infrastructure in multi-storey residential complexes of the largest cities.

There were also several theses defended by foreign scientists in Russia which were devoted to the architecture of apartment buildings. These dissertations were written by Sarath Boram (1997) and Lee Rasmey (2009) from Cambodia, Nguyen Khuyen (2004), Nguyen Van Tien (2013) and Nguyen Hong Loan (2013) from Vietnam.

In recent years, special attention has been given to the introduction of technologies for sustainable development. The first steps were made in dissertations of S. Molodkin ("Architectural formation principles of energy-efficient high-rise residential buildings", 2007), A. Voronin ("Formation principles of green spaces in residential multi-storey buildings", 2012), P. Semikin ("Architectural formation principles of high-rise buildings with renewable energy sources", 2014) and M. Blagova ("Architectural formation of commercial housing on social-functional basis with Rostov-on-Don as an example", 2015). Technical and technological aspects of high-rise housing construction were considered in dissertations of engineers, for example, in the works of O. Goryachev (2004), E. Sultanov (2006), O. 
Djachkova (2009), D. Strigin (2009), S. Dubinskiy (2010), V. Shcherba (2010), I. Sychev (2014), as well as in the thesis of Li Ruixin (2013) from China. Engineering geological problems in construction of high-rise buildings were examined by A. Zhukova (2011) and O. Ovechkina (2013). Some Russian researchers and economists focused on multi-storey real estate in new economic and environmental conditions (A. Melentyev, 2009, A. Oleinik, 2010, A. Balberov, 2011, E. Trushkovskaya 2011, E. Matveeva, 2012, and S. Shikhaliev, 2012).

Traditional and contemporary approaches to design and construction of multi-storey tall buildings are described in detail in works of Russian scientists V. Generalov along with E. Generalova, and O. Maslovskaya along with G. Ignatov. Their extensive researches generalized international experience [3-6].

\subsection{International practices and Russian prospects for the design and construction of multistory housing in the context of sustainable development}

Formation of the concept of sustainable development has stimulated new design and construction technologies and their development. Now systems of environmental certification based on the standards of BREEAM (Building Research Establishment Environmental Assessment Method, United Kingdom, 1990), LEED (Leadership in Energy and Environmental Design, United States, 1998) and DGNB (Deutsche Gesellschaft für Nachhaltiges Bauen, Germany, 2007) are frequently used for assessing the quality of highrise residential buildings. They have become a basis for the formation of national "green" standards in many countries, such as China and Russia. Besides, the World Green Building Council (WorldGBC) pays much attention to this trend. WorldGBC representative offices are currently located in 74 countries.

There are a few examples below illustrating successful implementation of some projects. For example, LEED Gold certificates were awarded to such American residential complexes as Macallen in Boston (architectural firm office dA) and Via Verde in New York (Dattner Architects, Grimshaw). A residential complex Triumph Park, Russia (Yashar Architects) and wooden residential buildings of a multipurpose complex in Bordeaux, France (Sou Fujimoto Architects) were designed in accordance with the requirements of BREEAM standard. DGNB silver certificate was awarded to the project of Gezhouba Hongqiao Purple County, a residential complex in Shanghai (China), and DGNB gold certified was earned by a project of a high-rise apartment house Skyline in Stuttgart (Germany).

There is scientific research underway in many countries of the world which is aimed at finding new technologies of sustainable architecture. According to the principles of sustainable development the main lines of research are environmental, social and economic. However, the most promising is a synergistic approach which combines these three lines. Indicators of sustainable development and sustainability indicators used in various fields and at different levels of detail are becoming now a kind of guidance system of urban environment systemic changes [7-9]. In 2010 Binh K. Nguyen and Hasim Altan, scientists from the University of Sheffield (United Kingdom), introduced a ranking system for assessing sustainability of existing high-rise construction projects [10].

According to it, principles of "green" architecture should take into account the entire life cycle of a building: construction, maintenance and demolition. At the same time, a complex of ecological problems has the most significant influence on the development of housing design principles in the early XXI century. Global climate change makes many countries to pay more attention to reducing energy consumption in the housing sector. External wall insulation systems which can be adapted to regional specific features are generally considered to be the most effective means here [11]. There are also experiments aimed at finding solutions to prevent formation of heat bridges, in particular, in window openings [12]. 
In connection with this, BIM-technologies of energy modeling are being introduced. For example, in Hong Kong, they are being spread into mass residential high-rise projects [13].

Attention to innovative solutions for high-rise buildings with the use of wood as renewable raw low-emission material grows every year $[14,15]$. Recently, an international team of researchers from Germany, the Netherlands, Italy and China has proved that a combination of CLT-panels with a concrete core and concrete pillars possess advanced capabilities [16].

In many countries introduction of typological innovations and quality of affordable housing improvement have become a priority approach to reduce social tension. More than thirty public energy efficient housing projects for low-income people are being implemented in several cities of Thailand. Application of even minimal social standards there makes it possible to improve the quality of life and cultural context [17]. Results of some other studies show economic efficiency of industrial methods used in high-rise housing construction [18, 19]. In Malaysia and Indonesia, for example, "green" technologies of resource conservation are applied not only to commercial housing, but also to rental housing that is built for the needs of young and elderly people [20-22].

However, it is known that one of the related problems that prevents an increase in construction of high-rise housing is its fire hazard. The solution for this problem is traditionally associated with special engineering facilities [23, 24], which make construction more expensive and, therefore, restricts the amount of potential buyers. Similar contradictions arise when designing ventilation and air conditioning systems in high-rise buildings $[25,26]$. In Russia, the introduction of sustainable technologies is in a formative stage. Despite the fact that in 1999 Russian representatives together with those from Australia, Great Britain, Spain, Canada, UAE, the United States and Japan were one of the founders of the World Green Building Council (WorldGBC), the first "green" standards were implemented in practice only in 2011, with a huge delay if compared with other countries [27]. Currently, rating systems for evaluating sustainability of residential and public buildings, designed by the State Corporation "Olimpstroy", by the National Association of builders (NOSTROY standards) and by an autonomous non-profit organization "Research Institute for sustainable development in construction" (GREEN ZOOM standards), are used on a voluntary basis. In actual practice, challenges of sustainable development, assessed by these systems, confront mainly energy efficiency activities, which have become one of the priorities of the national economy from 2008. In this respect, it is interesting to explore the real experience of designing and building high-rise housing in provincial cities of Russia. In these cities, there are no buildings, which would be nominated for compliance with "green" standards. At the same time, designers and builders there consistently introduce technologies that integrate environmental, social and economic aspects.

\section{Results}

The city of Samara, founded in 1586, is a typical Russian metropolis, emerging from the industrial era. There are neighbourhoods, zones of mixed construction, abandoned factory sites there alongside with the historic core area. There is a number of multistory buildings and residential complexes being erected in different parts of the city. In some cases, designers and developers introduce innovations corresponding to the goals of sustainable development of life activities. Let's look at some examples.

\subsection{Environmental aspects}

Over a period of several decades, the approach to designing the outer shell of the building has radically changed. Apartment blocks, built of reinforced concrete with the use of sliding 
formwork can serve as one of the earliest examples of the construction of buildings without thermal bridges in joints of slabs and enclosing walls. The first residential building was built in Samara in 1987-1988 as an experiment for realization of a typical project developed in Central Research Institute of Housing Engineering Design (Moscow). The authors of this project are such architects as A. Belokon, O. Tretyakov and V. Brandenburg, as well as such engineers as A. Lurie and E. Zaferidi. Similar buildings were erected in other cities of the USSR: in Alma-Ata, Minsk and Ufa. The first floor is designed to accommodate trade and service functions. There are eight apartments located on each residential floor. These apartments are two studios, four double and two triple flats. There are 152 apartments in this 20 -storey building. At its gable facades there are smoke controlled evacuation stairs. Brutal faces of the building are non-decorated and filled with balconies in staggered arrangement. Trying to reduce heat losses, many residents decided to glaze these summer spaces after several years of living in apartments (fig.1A).

At the turn of the XX century compact monolithic 18-storey towers were built in different part of Samara by means of the same sliding formwork technology. They were the last examples of the use of solid wall construction with no insulation.

"Ladya" (2004-2008), a residential complex designed by the architects Yu. Koryakin, B. Zhukov, A. Koryakina, T. Vasilyeva, T. Khimchak, N. Ilyasova, D. Lychev, I. Vinshu with Volgatransstroy as a developer, became a breakthrough project. It was the first high-rise residential complex in Samara in which monolithic framework and energy efficient ventilated facades were purposefully introduced. The complex consists of two 25 -storey towers with a height of 95 meters and one 18-storey tower with a height of $70 \mathrm{~m}$, which are connected with the help of stylobate with social infrastructure facilities. In its underground level, there is a parking for 289 vehicles and an autonomous roof boiler room that allows precise control of the flow of heat-transfer medium (fig.1B).
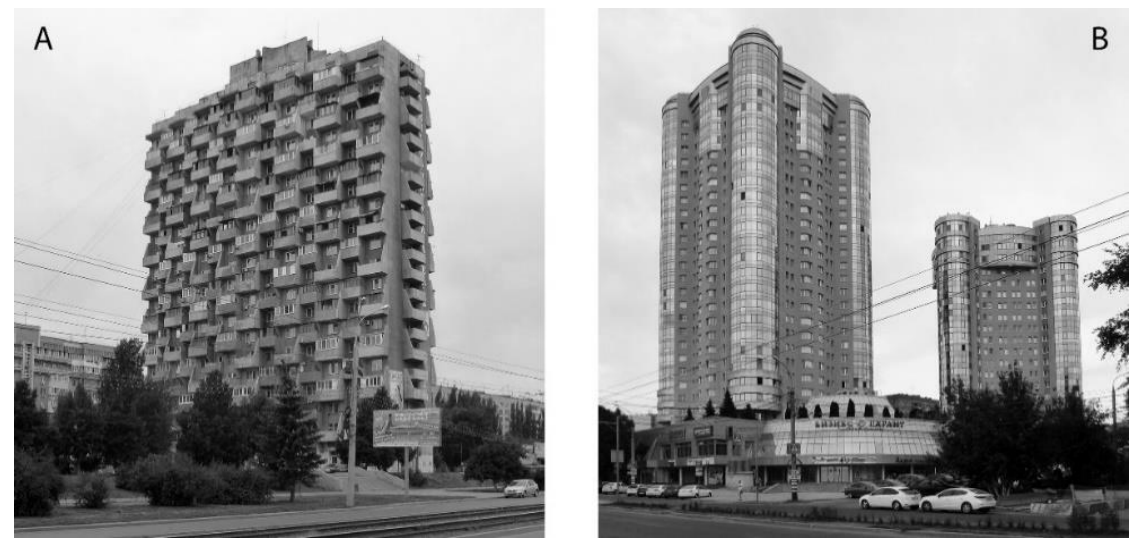

Fig. 1. The first high-rise residential buildings in the city of Samara.

This project made it possible to start massive erection of high-rise residential buildings with fundamentally new approaches to resources saving. Currently, most residential buildings of 12 floors and above are erected on the basis of monolithic framework with the use of two main types of facade systems -"wet" and "ventilated". The choice is mostly dictated by the target consumer group. The first technology is frequently used in the construction of affordable housing, the second is used in the construction of premium-class objects.

Such geometrical features of the residential complex "Ladya" as the streamlined shape of the towers and the absence of large consoles also help reduce energy consumption. A similar formation is used, for example, in the residential complex "Argo", designed by A. Gerasimov's project team (with A. Gerasimov, A. Nikolaeva, V. Charkov as architects and 
A. Gribanov, D. Gerasimov as engineers and "Stroyresurs" as a construction company). Its three 24-story towers house a total of 552 apartments.

\subsection{Social aspects}

Changes in national housing policy are clearly reflected in the development of a typology of innovations which take into account diversity of social needs of the population. These innovations occur primarily in housing construction of different price categories, in diversity of growing social infrastructure, as well as in compliance with the principles of forming an inclusive living environment.

Real estate agencies in Samara define the following categories: "economy", "comfort", "business" and "elite". Now "economy" and "comfort" categories of real estate are most popular on the market. Such housing is most commonly built in the central or fringe parts of the city. Let us go through Samara Regional Fund of housing and real estate mortgages experience. Local architects were invited to develop space-planning decisions of high-rise housing. Thus, "Oberon", a local architectural firm, designed a project of a 21 -storey residential building with 256 apartments within the boundaries of Antonova-Ovseenko, Blucher and Soviet Army streets (with E. Krupnova, E. Kazachkova as architects and S. Dudarenko as an engineer). It is important that apartments of "economy" class are often commissioned in final finishing. Buyers are offered a choice of several design options.

The economy-class housing group also include a residential complex «Dimitrova 74A" (by an architectural firm "Sreda", its chief architect A. Suvidova, and its chief engineer K. Zhuchkov), a residential complex "Raduzhniy Elite" (2014, chief architect T. Khimchak, chief engineer V. Fedoseev and an association of construction companies "Bereg" as a developer), a residential complex "Favorit" (designed by an architecture-construction company "Arkada" with S. Balabanov being an architect and "Premier-Investstroy" being a developer), as well as a residential complex "Olimpia Park", located in the immediate vicinity of the World Cup 2018 football stadium construction site (by A. Gerasimov's project team with V. Lavrentiev and A. Nikolaeva as architects, D. Gerasimov as an engineer and a construction company "Russian Bazaar" as a developer). Number of stories in these sites ranges from 16 to 25 , the height of buildings is from 2.24 to $2.7 \mathrm{~m}$. There are public accommodations and facilities in the lower floors of some complexes. Indoor or underground parking is generally not provided. In the outdoor parking, parking spaces number does not exceed $20 \%$ of the number of apartments (fig.2).
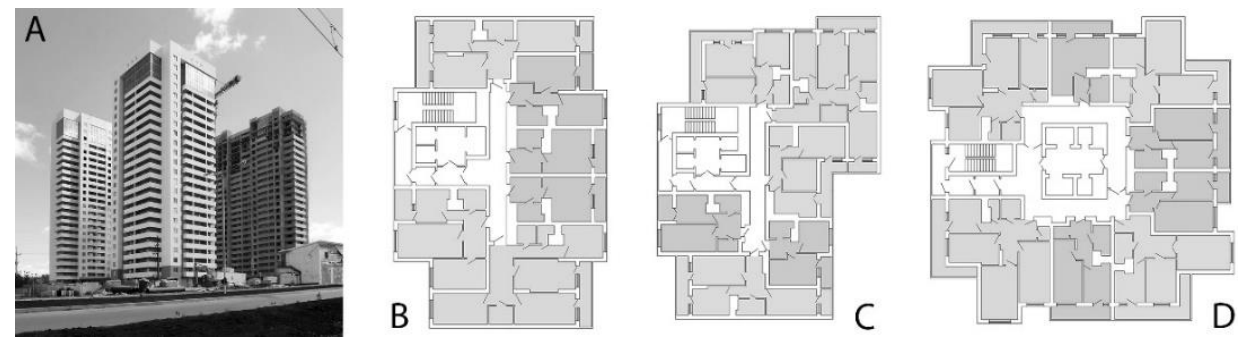

Fig. 2. Residential complex "Olimpia Park". A - overall view; B, C, D - variants of the residential units (materials provided by the authors of the design).

A business-class group includes such residential complexes as "Step Green House" (by an architectural firm "Arthouse" with T. Rychkova, A. Barannikov, A. Varenov as architects, E. Bogdanov as an engineer, and "Samarazhilinvest" as a developer, fig. 3), "Panorama" (Samaragorproekt project team with D. Khramov as an architect and "Stroykom" as a developer), "Imperial" (with I. Khakhalin as an architect and "Stroyekonom" group as a 
developer), a residential complex "Fregat" (designed by an architectural firm "Oberon" with E. Krupnova, A. Semenov as architects, E. Nikitin as an engineer and "AllianceManagement" as a developer), a residential complex "Parus" (designed by an architectural firm «Oberon» with A. Semyonov as a chief architect, K. Tracevskiy as a chief engineer and "Alliance-Management" as a developer).
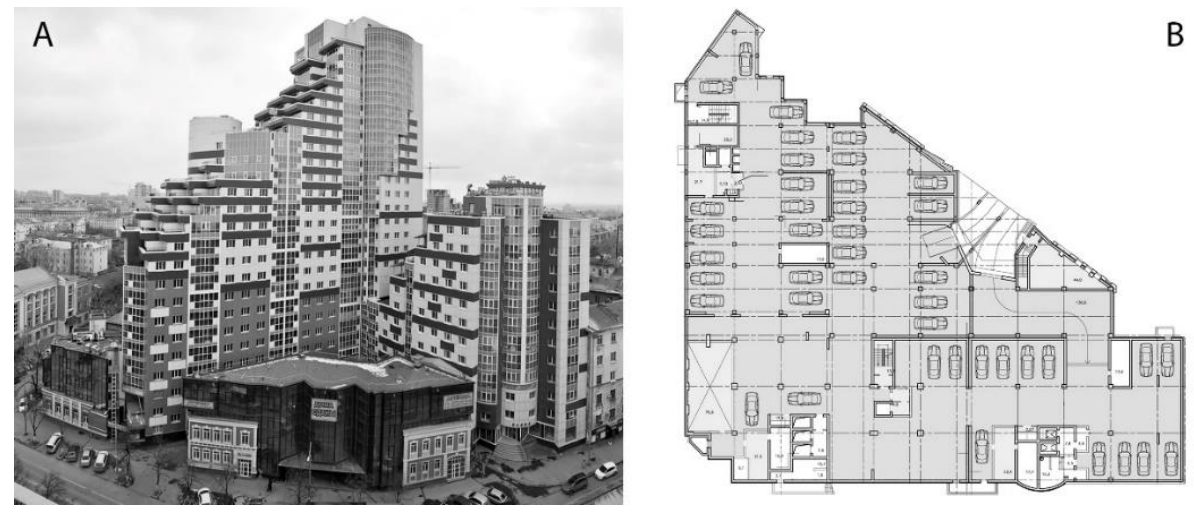

Fig. 3. Residential complex " Step Green House". A - overall view; B - plan of the underground floor (materials provided by the authors of the design).

These residential complexes are located either in the historical part of Samara, or in areas with picturesque landscapes, not far from the banks of the Volga River. The eight of residential premises there are ranges from $2.85 \mathrm{~m}$ to $4.0 \mathrm{~m}$. In most cases, lower floors are for rent, and parking lots are located in the underground levels. Final finishing in the apartments is not provided. There is an option of re-planning and exclusive design solution given to owners.

It is interesting to compare sizes of apartments in new residential high-rise buildings in Samara with federal rules of designing housing facilities intended for social needs (Table 1).

Table 1. Comparative analysis of apartments space in residential complexes of Samara

\begin{tabular}{|c|c|c|c|c|}
\hline \multirow[t]{3}{*}{ Address } & \multicolumn{4}{|c|}{ Types of apartments } \\
\hline & Studio & $\begin{array}{l}\text { 1-room } \\
\text { apartment }\end{array}$ & $\begin{array}{l}\text { 2-room } \\
\text { apartment }\end{array}$ & $\begin{array}{l}\text { 3-room } \\
\text { apartment }\end{array}$ \\
\hline & \multicolumn{4}{|c|}{ Space, $\mathrm{m}^{2}$} \\
\hline $\begin{array}{l}\text { A set of rules } \\
\text { (SP 54.13330.2011, Table 5.1) }\end{array}$ & - & $28,0-38,0$ & $44,0-53,0$ & $56,0-65,0$ \\
\hline \multicolumn{5}{|c|}{ "ECONOMY»" } \\
\hline Dimitrova 74A & & $\geq 39.8$ & $\geq 58.2$ & $\geq 107.1$ \\
\hline $\begin{array}{l}\text { Boundaries of Antonova-Ovseenko, } \\
\text { Blucher and Soviet Army streets }\end{array}$ & $\geq 51.1$ & $\geq 36.3$ & $\geq 58.1$ & \\
\hline "Olympia Park" & & $\geq 30.0$ & $\geq 58.2$ & $\geq 96.0$ \\
\hline "Raduzhniy Luxe" & & $\geq 39.0$ & $\geq 55.9$ & $\geq 82.1$ \\
\hline "Favorite" & & $\geq 39.3$ & $\geq 60.4$ & $\geq 75.7$ \\
\hline \multicolumn{5}{|c|}{ "COMFORT" } \\
\hline "Argo" & & $\geq 31.0$ & $\geq 70.0$ & $\geq 99.0$ \\
\hline "Volga" & & $\geq 49.0$ & $\geq 69.9$ & \\
\hline "Raketa" & & $\geq 45.7$ & $\geq 71.5$ & $\geq 108.0$ \\
\hline \multicolumn{5}{|c|}{ "BUSINESS" } \\
\hline "Brig" & & $\geq 57.0$ & & $\geq 102.7$ \\
\hline "Ilyin Plaza" & & $\geq 45.5$ & $\geq 57.8$ & $\geq 98.2$ \\
\hline "Imperial" & & $\geq 52.0$ & $\geq 76.4$ & \\
\hline "Liverpool" & & $\geq 33.0$ & $\geq 65.7$ & $\geq 70.0$ \\
\hline
\end{tabular}




\begin{tabular}{|l|l|l|l|l|}
\hline "Panorama" & $\geq 56.5$ & $\geq 92.4$ & $\geq 102.3$ \\
\hline "Fregat" & & $\geq 30.0$ & $\geq 60.0$ & \\
\hline \multicolumn{4}{|c|}{ "ELITE" } \\
\hline "Parus" & & $\geq 44.1$ & $\geq 62.8$ & $\geq 93.5$ \\
\hline
\end{tabular}

Now, two residential complexes of elite class in Samara (that is "Ladya" and "Step Green House") have adopted an innovative solution: an operated ballasted roof increasing the comfort of living (fig.1). There is a general recreational space constructed on the stylobate of the first complexes and individual terraces are built on the ledges of the second.

After regulations on needs of people with limited mobility have been introduced in Russia, all residential buildings regardless of their category of comfort have to be equipped with entrance ramps. Vertical inter-floor transfer is made with the help of elevators.

\subsection{Economic aspects}

From the viewpoint of "green" economy, the growth in efficiency of urban land use, cost reduction during construction and operation of buildings [28, 29] as well as infrastructure development for small businesses are the most appropriate means to solve economic problems in Russian architectural sphere.

High-rise housing construction allows to increase population density, to reduce the length of transport communications and mainstream engineering systems. It also raises the possibility of violations of human-induced load values allowable for urban environment. In the Russian Federation this problem is still in the discussion stage [30-32], and regulations for territory and premises insolation serve as the main constraining factor at the moment.

The real way to reduce the cost of construction, for both "business" and "elite" segments in Samara is to launch on and the same project several times. One of the most replicated projects here is the project of a dwelling-house of tower-type, included into the residential complex "Argo". It has been lately replicated in residential complexes "Volga", "Pushkinskiy" and "Raketa" (by A. Gerasimov's project team with construction companies "Stroyproektservis", "Samara project" and "Grad" as developers, respectively). In different conditions, these frame-monolithic buildings with protecting ceramic brick walls are of 17 or 25 floors.

Many designers achieve savings in operating costs by increasing the width of buildings, by optimizing the degree of compactness of the planning decision, by rejecting the use of open summer spaces that are not protected from the effects of precipitation [33].

Over the past twenty years in Russia, as well as in Samara, there is a change in forms of organization of social services. For example, built-in premises for rent are included into the structure of new residential complexes already at the design stage [34]. Shops, pharmacies, hairdressers, kindergartens, banks, travel companies, medical clinics, etc. come closer to the consumer and increase the urban environment sustainability.

\section{Discussion}

A study of modern experience of designing and building high-rise residential complexes in Samara makes it possible to recognize a whole set of unsolved problems that prevent ecological and social comfort of accommodation from progressive improvement, as well as decrease economic efficiency of using territories and objects.

First of all, these problems are connected with the development of high-rise building in the historical part of the city. On the one hand, it obvious consumer appeal come into collision with established morphological randomness, the presence of old housing stock and a significant number of buildings which are of arguable historical and cultural value [35]. All 
this does not correspond to the concept of sustainable urban development. On the other hand, attempts to include multistory (above 20 floors) housing into the structure of the historical urban fabric while maintaining the traditional quarterly schematics and observing "the red lines" of construction lead to the transformation of aerodynamic conditions, increase transport loads, contribute to spontaneous parking formation, to the reduction and extinction of green spaces in courtyards.

The main problems of center and fringe parts of the city are those of insufficient saturation of residential spaces with small businesses, as well as the use of obsolete composite and technological solutions typical of architecture of the late socialism era. A functional reserve here lies in active introduction of free planning into the practice of economy-class housing, which allows to take into account the needs of people in a wide range of ages, from youth to seniors.

\section{Conclusions}

The research carried out in Samara demonstrates that various architectural and spatial, functional planning and construction-technological solutions are being introduced in the architecture of modern high-rise residential buildings and housing complexes. This fact underlines positive dynamics of the principles of sustainable development implementation. Resource-saving technologies here are used most widely. In particular, the process of increasing thermal comfort and energy-efficiency of buildings affected housing in all price categories.

However, the analysis of the current situation makes it possible to conclude that, despite significant changes in the formation of service infrastructure of residential areas, there is an open question of real estate proposals and their correspondence with socio-demographic needs and economic opportunities of society.

\section{References}

1. L.A. Viktorova, Tall Buildings - the Pros and Cons Of Building, Architecture and Construction of Russia, 10, 2-11 (2012)

2. P. P. Semikin, P. V. Semikin, Perspective Types of High-Rise Buildings, Regional Architecture and Art Schools, 1, 132-138 (2015)

3. V. P. Generalov, Features of Designing High-Rises Houses, 296 (Samara, 2009)

4. V. P. Generalov, E. M. Generalova, High-Rise Residential Buildings and Complexes. Singapore, Experience in High-Rise Housing Design and Construction, 400 (Samara, 2013)

5. V. P. Generalov, E. M. Generalova, Perspectives of High-Rise Housing Typology Development. Future of Cities. Vestnik SGASU, Town Planning and Architecture, 1(18), 10-18 (2014)

6. O. V. Maslovskaya, G. E. Ignatov, Conception of Height in the Design of Urban Environment, VSUES, 212 (Vladivostok, 2012)

7. D. Kyrkou, R. Karthaus. Procedia Engineering, 21, 204 - 211 (2011) doi:10.1016/j.proeng.2011.11.2005.

8. G. Barbano, A. Egusquiza. Energy Procedia, 78, 1853 - 1858 (2015) doi: 10.1016/j.egypro.2015.11.332 
9. T. Ya. Vavilova, Foreign Experience in Using the Sustainable Development Indicators to Assess the Quality of Urban Environment, Sustainable Development of Urban Environment, 6-9 (SGASU, Samara, 2016)

10. B. K. Nguyen, H. Altan, Procedia Engineering, 21, 387 - 394 (2011) doi:10.1016/j.proeng.2011.11.2030.

11. S. K. Saha, Cost Effective Thermal Wall System for Residential Housing, Procedia Engineering, 14, 1913-1919 (2011) doi:10.1016/j.proeng.2011.07.240.

12. Pham Thi Hai Ha, Procedia Engineering, 142, 54 - 160 (2016) doi: 10.1016/j.proeng.2016.02.026

13. Y. Zhao, W. Pan, Y. Ning, Procedia Engineering, 118, 614 - 621 (2015) doi: 10.1016/j.proeng.2015.08.494

14. Roman Milwicz, Piotr Nowotarski. Procedia Engineering, 122, 158 - 165 (2015) doi: 10.1016/j.proeng.2015.10.020.

15. J. L. Skullestad, R. A. Bohne, J. Lohne. Energy Procedia, 96, 112 - 123 (2016) doi: 10.1016/j.egypro.2016.09.112.

16. J. W. G. Van de Kuilen, A. Ceccotti, Zhouyan Xia, Minjuan He, Procedia Engineering, 14, 1621 - 1628 (2011) doi:10.1016/j.proeng.2011.07.204.

17. W. Tanaphoom, D. Bart, Procedia Environmental Sciences, 28, 689 - 697 (2015) doi: 10.1016/j.proenv.2015.07.081

18. Le Minh Ngo, Procedia Engineering, 142, 42-47 (2016) doi: 10.1016/j.proeng.2016.02.011.

19. Malay Dave, Bruce Watson, Deo Prasad, Procedia Engineering, 180, 676 - 686 (2017) doi: 10.1016/j.proeng.2017.04.227.

20. M. S. Suhaida, N. M. Tawil, N. Hamzah, A. I. Che-Ani, H. Basri, M.Y. Yuzainee. Procedia Engineering, 20, 345 - 353 (2011) doi:10.1016/j.proeng.2011.11.176

21. A. R. Musa, N. M. Tawil, S. M. Sood, A. I. Che-Ani, N. Hamzah, H. Basri. Procedia Engineering, 20, 466-373 (2011) doi:10.1016/j.proeng.2011.11.189

22. Ed. E. Pandelaki, W. S. B. Pribadi, Procedia Environmental Sciences, 20, 146 - 153 (2014) doi: 10.1016/j.proenv.2014.03.020

23. Adam Cowlard, Adam Bittern, Cecilia Abecassis-Empis, Jose Torero, Procedia Engineering, 62, 169 - 181 (2013) doi: 10.1016/j.proeng.2013.08.053

24. T. Yu Eremina, I. A. Egorov, Problems of evacuate people from high-rise buildings during fires, Technology of technosphere safety, 3(55), 21 (2014)

25. W. Sujatmiko, H. K. Dipojono, F.X. Nugroho S., Soegijanto, Procedia Environmental Sciences, 28, 360 - 369 (2015) doi: 10.1016/j.proenv.2015.07.045

26. Xi Chen, Hongxing Yang. Energy Procedia, 88, 748 - 753 (2016) doi: 10.1016/j.egypro.2016.06.065.

27. T. Ya.Vavilova, I. V. Zhdanova, Consumer Properties of Architectural Solutions for Housing and "Green" Standards, Tradition and Innovation in Construction and Architecture, 333 - 334 (SGASU. Samara. 2013)

28. Fam Khak K, Innovative methods of solution designs assessment of efficiency in highrise construction, "FES: Finance. Economy. Strategy", 9, 19a - 23 (2011)

29. L. P. Lavrov, F. V. Perov, High-Rise Buildings: the Wrong Vector of Housing Construction Development, Bulletin of Civil Engineers, 5(58), 16 - 27 (2016)

30. K. A. Karelina, High-rise buildings: the opinion of experts and residents to high-rise construction, APRIORY: Natural and Technical Sciences, 1, 11 (2016) 
31. A. I. Androsov, A. V. Kopyeva, O. V. Maslovskayam Analysis of Foreign and Domestic Experience in the Design of Housing for the Elderly, The New Ideas of New Century, 2, 12 - 16 (Pacific National University, 2017)

32. G. A. Ptichnikova, "Unfair City": Urban Space as a Reflection of Public Relations, Sociology of City, 3, 47 - 54 (2012)

33. I. V. Zhdanova, T. Ya. Vavilova, N. A. Kalinkina, Life Cycle Extension of Mass Residential Housing Development, Architectural Innovations. Sustainable Development of Urban Environment, 124 - 127 (SGASU, Samara, 2016)

34. A. A. Kolosovskaia, N. D. Potienko, Evolution of Topological Structure of Rental Housing in Foreign Countries, Urban Construction and Architecture, 3(24), 109 - 115 (2016)

35. G. A. Ptichnikova, Architectural Symbols of Globalization in the Russian Cities: Skyscrapers and City, Vestnik VolgGASU, Construction and architecture, 15, 173 - 178 (2009) 